\title{
Penguatan Sikap Percaya Diri melalui Dreams Book bagi Siswa Kelas I SDN Tegalombo I Kalijambe Sragen
}

\author{
Yan Vita \\ SDN Tegalombo 1 UPT Dinas Pendidikan Kecamatan Kalijambe \\ e-mail:yanvita27@yahoo.com
}

\begin{abstract}
This article aims to explore the reinforcement of confidence through dreams book. In the early condition, the students have low self-confidence. To increase theself-confidence of the students, the teacher begins to explore the dreams of the students and make the students realize their dreams through dreams book. Through qualitative descriptive, this research described how to implement dreams book in the learning process. The teacher asked the students to make simple book consisted of four pages. As the evaluation, the teacher used some assessments, such as observation, self-assessment, and friend assessment. The teacher asked the student to fill out the sheet of self-assessment rubric and friend assessment rubric. For the observation, the teacher made observation rubric. From the result of this evaluation, the teacher concluded that self-confidence of the students showed improvement. As much as 34\% and 36\% of students obtain score 3 and 4, respectively. Therefore, the students who get a score above the KKM (Kriteria Ketuntasan Minimal) is $80 \%$. It means that the score in every indicator of self-confidence showed improvement.
\end{abstract}

Keywords: Self-confidence, dreams book, 


\section{Pendahuluan}

Hasil akhir pembelajaran dalam kurikulum 2013 adalah peningkatan dan keseimbangan antara kemampuan untuk menjadi manusia yang baik (soft skills) dan manusia yang memiliki kecakapan dan pengetahuan untuk hidup secara layak (hard skills) dari peserta didik yang meliputi aspek sikap, keterampilan dan pengetahuan (Dirjen PAIS, 2014:2). Dalam proses pembelajaran, kompetensi sikap spiritual dan sikap sosial dikembangkan dalam setiap kegiatan sekolah dengan pendekatan pembelajaran tidak langsung (indirect teaching) (Dirjen Pais, 2014). Kunandar (2014:18) menyatakan di sekolah anak didik belum mendapatkan internalisasi nilai secara matang dan bermakna. Hal ini disebabkan dalam pembelajaran masih menitik beratkan pada aspek kognitif sehingga aspek afektif dan psikomotorik yang bermuatan karakter kurang diperhatikan. Kemampuan afektif harus menjadi bagian dari tujuan pembelajaran di sekolah, yang akan dicapai melalui kegiatan pembelajaran yang tepat. Dalam kurikulum 2013 kompetensi sikap tidak diajarkan dalam proses belajar mengajar, tetapi untuk diimplementasikan atau diwjudkan dalam tindakan nyata oleh peserta didik (Kunandar, 2014:104).

Karakter berupa kualitas kepribadian bukan barang jadi, tetapi melalui proses pendidkan yang diajarkan secara serius, sungguh sungguh, konsisten dan kreatif yang dimulai dari unit terkecil keluarga, masyarakat dan lembaga pendidikan (Jamal Ma'mur Asmani, 2013:30). Nilai-nilai pendidikan karakter masih jauh dari yang diharapkan. Banyak pendidik yang hanya menonjolkan aspek kemampuan intelektualitas belaka dan meninggalkan nilai-nilai etika (Baidi, 2014:205). Namun faktanya, dalam kurikulum 2013, kompetensi sikap (KI-2) belum mendapat proporsi yang seimbang dengan kompetensi yang lain. Dalam kompetensi sikap, hanya difokuskan pada penilaian dan tidak dibarengi dengan bagaimana menanamkan sikap yang diinginkan dilakukan kepada siswa. Ini menjadi rancu, ketika amanat kurikulum 2013 yang menekankan pada penumbuhan karakter siswa, namun dalam kompetensi sikap hanya pada taraf penilaian.

Hal ini tentu sangat tidak adil untuk siswa. Mereka hanya dilihat bagaimana sikapnya tanpa dibimbing dan diarahkan bagaimana bersikap yang benar sesuai yang diharapkan. Jadi sangat naif jika kita menuntut perbaikan sikap siswa namun kita 
tidak mengarahkan bagaimana agar mereka mampu menjadi pribadi kuat yang berkarakter.Ini menjadi hal yang tidak mudah untuk guru. Banyaknya keluhan dari masyarakat tentang buruknya mental generasi muda, merosotnya nilai-nilai moral serta rendahnya sikap sosial menjadi beban berat bagi para guru. Meskipun pada kenyataannya, hal ini bukan satu-satunya menjadi tanggung jawab guru. Banyak pihak yang seharusnya berbenah untuk memperbaiki situasi ini. Guru melalui pembelajaran diharapkan mempunyai andil yang besar dalam mengatasi masalah di atas. Jika dahulu guru hanya menyampaikan ilmu pengetahuan, sekarang guru juga bertugas untuk membimbing siswa untuk menjadi pribadi yang lebih baik. Hal ini tentu tidak mudah, butuh kreatifitas,ketekunan, kesabaran dan kerja keras.

Pada kompetensi inti sikap sosial, sikap anak yang dinilai antara lain adalah sikap percaya diri. Fakta masih banyaknya siswa yang kurang percaya diri memang masih dijumpai. Salah satu indikator yang bisa diambil contoh rendahnya sikap percaya diri siswa adalah masih banyaknya siswa yang berusaha curang dalam setiap ujian, banyaknya kasus bocornya soal ujian bukti kurang percaya diri siswa. Padahal mungkin tanpa mencari kunci atau bocoran soalpun mereka akan mampu mengerjakan dengan baik.

Menanamkan sikap percaya diri pada siswa merupakan salah satu tugas guru. Siswa diharapkan mampu mencontohkan dan menunjukkan percaya diri dalam kehidupan sehari-hari. Tentu bukan hal yang mudah untuk membangkitkan sikap percaya diri bagi siswa. Namun harus diyakini bahwa semua siswa pasti mempunyai mimpi dan itu berarti modal dasar untuk menumbuhkan sikap percaya diri mereka.

Mimpi sifatnya masih merupakan alam pikiran dalam bentuk hayalan, lamunan dan imajinasi. Agar alam pikiran menjadi alam benda (wujud) maka membutuhkan media perantara. Jika alam bawah sadar bisa merespon dengan baik apa yang menjadi impian, maka pikiran akan memerintahkan tubuh untuk merespon dan melakukan tindakan yang akan mewujudkan impian tersebut. Alam bawah sadar sangat cepat merespon yang bentuknya visual. Jika bentuk visual ini bisa dibayangkan seolah-olah nyata, sudah bisa dirasakan, dipegang dilihat maka jalan untuk mewujudkannya menjadi semakin cepat

| Volume. 1, No. 2, Juli-Desember 2016 
Berawal dari itulah, untuk membangkitkan sikap percaya diri anak, dicoba dimulai dari menggali mimpi-mimpi mereka dan membuat mereka berusaha untuk mewujudkan mimpi-mimpi mereka itu. Penggunaan media pembelajaran Dreams Book diharapkan mampu untuk menumbuhkan sikap percaya diri siswa. Dreams book merupakan buku mimpi yang akan mereka tulisi dengan apa yang mereka inginkan dan apa yang akan mereka lakuakn untuk mewujudkan mimpi mereka tersebut.Penelitian ini akan membahas bagaimana menumbuhkan sikap percaya diri siswa melalui dreams book pada siswa kelas 1 di SDN Tegalombo 1 tahun pelajaran $2015 / 2016$.

\section{Kompetensi Sikap Percaya Diri}

Sikap merupakan kecenderungan untuk berbuat dan berperilaku kepada suatu obyek (Kemdikbud, 2015:50). Penilaian sikap ditujukan untuk membina perilaku sesuai budi pekerti dalam rangka pembentukan karakter peserta didik. Dalam kurikulum 2013 kompetensi sikap ada dua yaitu KI-1 Sikap Spiritual dan KI2 Sikap Sosial. Pada KI-2 Sikap Sosial aspek penilaian terdiri dari jujur, disiplin, tanggung jawab, santun, peduli dan percaya diri.

Menurut Joseph (1998:118) sebagaimana dikutip Khuriyah dan Junanto (2014:260) percaya diri merupakan alat yang paling efektif untuk meningkatkan kualitas diri manusia. Dalam kurikulum 2013, pada aspek percaya diri, catatan perilaku siswa dilakukan sesuai indikator pada aspek percaya diri. Indikator aspek percaya diri antara lain (kemdikbud, 2015: 64):

a. Berani tampil di depan kelas

b. Berani mengemukakan pendapat

c. Berani mencoba hal baru

d. Mengemukakan pendapat terhadap suatu masalah atau topik

e. Mengajukan diri sebagai ketua kelas atau pengurus kelas lain

f. Mengajukan diri untuk mengerjakan tugas atau soal di papan tulis

g. Mencoba hal-hal baru yang bermanfaat

h. Mengungkapkan kritikan membangun terhadap karya orang lain

i. Memberikan argumen yang kuat untuk mempertahankan pendapat. 
Pelaksanaan penilaian kompetensi sikap dilakukan setiap hari selama proses pembelajaran berlangsung. Teknik penilaian sikap dilakukan dengan observasi, jurnal, penilaian diri dan penilaian antar teman. Instrumen yang digunakan guru adalah daftar cek atau skala rating yang disertai rubrik, sedang jurnal berupa catatan pendidik (Yan Vita, 2014: 45).

\section{Dreams Book (Buku Mimpi)}

Ketika siswa bisa mengidentifikasi sebuah benda, dia memberi benda tersebut sebuah makna sesuai pengalaman yang dia peroleh, dan dengan begitu ingatan akan lebih tersimpan dengan baik (Gudjons, 1997: 7-8). Terdapat hubungan yang erat antara tindakan dengan ingatan. Jika indera yang digunakan lebih banyak, maka daya ingatnya akan lebih tinggi. Karena manusia menyimpan $20 \%$ dari apa yang dia dengar, 30\% dari apa yang dia lihat, $80 \%$ dari yang disimpulkannya sendiri dan menyimpan 90\% dari apa yang dia lakukan sendiri (Gudjons, 1994).

Dreams Book atau buku impian adalah sebuah buku catatan tentang impian-impian kita, harapan, keinginan atau cita-cita apa yang akan kita ingincapai. Dreams Book bisa dibuat sendiri dari kumpulan kertas hvs kosong yang dijilid menjadi sebuah buku (seperti hal nya note book) dengan sedikit kreasi buat sampul sedemikian menarik, dan anda beri judul Dreams Book. Dihalaman awal sebaiknya dipasang foto orang-orang yang anda cintai misal: ibu dan bapak, pasangan hidup anda dll. Jadi disaat kita lelah menggapai mimpi, maka ingatlah orang-orang yang anda cintai untuk dijadikan motivasi.

Bermain Dreams Book merupakan suatu permainan/cara untuk mengajak siswa memiliki kemampuan merumuskan keinginan (cita-cita) melalui gambar visual dan memiliki kepercayaan diri untuk menyampaikannnya kepada orang lain. Permainan ini menggunakan buku yang dibuat sendiri oleh siswa untuk merefleksikan apa yang menjadi keinginan mereka.

\section{Langkah-langkah Pemanfaatan Dreams Book}

Tujuan pembelajaran adalah untuk menumbuhkan percaya diri siswa. Bahan yang digunakan dalam pembelajaran antara lain koran bekas, majalah kertas karton, 
foto diri terbaik siswa, gunting dan lem. Sedangkan proses pemanfaatan Dreams Book adalah:

1. Setiap siswa diminta untuk membawa koran bekas, majalah, dan gambar-gambar figur seperti pemain sepak bola, pelukis, tentara, polisi, dokter, guru, petani, karyawan dan sebagainya, gunting dan lem;

2. Setiap siswa diminta membuat buku terbuat dari karton yang terdiri dari empat halaman;

3. Guru mengajak siswa untuk memikirkan cita-citanya;

4. Ajak siswa untuk menempel foto dirinya dan menuliskan nama panggilannya di bawah foto serta cita-citanya di bahah nama panggilannya pada buku halaman pertama;

5. Guru mengajak siswa untuk mengatahui kehebatan dirinya;

6. Ajak setiap siswa untuk memilih gambar dari koran, majalah atau gambar figur yang menyimbolkan cita-citanya dan menempelkannya pada halaman kedua;

7. Ajak siswa untu menggunting gambar-gambar yang ada di koran atau majalah yang menggambarkan kehebatannya lalu tempel pada halaman ketiga;

8. Ajak setiap siswa untuk menggunting gambar yang ada di koran atau majalah yang menggambarkan jalan atau cara untuk mencapai cita-citanya;

9. Setelah semua pekerjaan selesai berikan kesempatan kepada siswa untuk mempresentasikan hasil pekerjaannya di depan kelas;

10. Setelah seluruh peserta mempresentasikan cita-cita dan kenginannya berikan penekanan pentingnya cita-cita dan kepercayaan diri untuk mencapai cita-cita tersebut.

Langkah-langkah yang dilakukan dalam menerapkan model pembelajaran tentu tidak lepas dari mengamati, menanya, mengeksplore, mengasosiasi dan mengkomunikasikan.

1. Mengamati. Siswa mengamati media pembelajaran berbasis ICT yang digunakan guru. Siswa mengamati video tentang percaya diri.

2. Menanya. Melalui motivasi guru siswa mengajukan pertanyaan terkait tayangan yang mereka lihat. 
3. Mengeksplore. Melalui metode bermain Dreams Book, siswa diajak untuk mendalami materi percaya diri

4. Mengasosiasi. Siswa mulai menghubungkan apa yang mereka lihat dalam tayangan dengan apa yang mereka dramakan/ mainkan.

5. Mengkomunikasi. Siswa bersama-sama guru membuat kesimpulan, guru memberi penguatan

\section{Hasil Penelitian}

\section{Sikap Percaya Diri Siswa}

Siswa kelas 1 SDN Tegalombo 1 berjumlah 20 siswa terdiri dari 11 siswa laki-laki dan 9 siswa perempuan. Kondisi awal sebelum memanfaatkan Dreams Bookdidasarkan pada wawancara dengan guru kelas 1 dan juga salah satu siswa.Menurut Ibu Tri Wulandari selaku guru kelas 1 pada wawancara tanggal 15 Maret 2013 tentang sikap percaya diri siswa kelas 1 adalah: "Sikap percaya diri siswa dulu masih rendah, siswa tidak berani mengungkapkan apa yang ada di benak mereka. Ketika diminta untuk maju kedepan kelas juga sangat sulit”.

Sedangkan wawancara dengan salah satu siswa kelas 1 yang bernama Calvin pada tanggal 15 Maret 2013, dia mengungkapkan bahwa: "Saya tidak berani maju kedepan karena malu, juga takut kalau salah".Berdasar observasi yang dilakukan, didapat hasil bahwa dari 20 siswa hanya 8 siswa yang aktif dan menunjukkan indikator sikap percaya diri. Artinya hanya 40\% siswa yang menunjukkan sikap percaya diri yang tinggi.Salah satu siswa kelas 1 yang bernama Usmah Luhur Tri Hapsari menyatakan bahwa: "Bu Guru menyuruh kami membuat buku mimpi dalam pelajaran Pendidikan Agama Islam dan Budi Pekerti. Kami senang, belajar lebih menyenangkan. Saya menempel cita-cita saya di buku, saya harus giat belajar untuk mencapai cita-citaku. Sekarang saya tidak malu lagi, karena saya harus bangga pada diri saya sendiri”. Hasil evaluasi tentang Sikap percaya diri setelah dilakukan pembelajaran dengan memanfaatkan Dreams Book tercantum dalam Tabel 1.

\section{Kurikulum}

Kurikulum yang digunakan di SDN Tegalombo 1 tahun pelajaran 2015/2016adalah kurikulum 2013. Meskipun SDN Tegalombo 1 bukanlah Sekolah 
Dasar rintisan pengguna kurikulum 2013, namun kebijakan kabupaten Sragen mengharuskan semua SD menerapkan kurikulum 2013. Dengan menggunakan kurikulum 2013 artinya ada 4 kompetensi yang harus dikuasai siswa yaitu kompetensi sikap spiritual, sosial, pengetahuan dan keterampilan. Pada kompetensi sikap sosial aspek yang dinilai antara lain jujur, disiplin, tanggung jawab, santun, peduli dan percaya diri. Pada penelitian ini hanya difokuskan pada sikap percaya diri.

Tabel 1. Hasil evaluasi sikap percaya diri setelah menggunakan Dreams Book

\begin{tabular}{|c|l|c|c|c|c|}
\hline \multirow{2}{*}{ No } & \multicolumn{2}{|c|}{ Indikator } & \multicolumn{4}{|c|}{ Skor/ jumlah siswa } \\
\cline { 3 - 6 } & & 1 & 2 & 3 & 4 \\
\hline 1 & Berani bertanya/berpendapat & 2 & 4 & 8 & 6 \\
\hline 2 & Melakukan sesuatu tanpa ragu & 3 & 4 & 5 & 8 \\
\hline 3 & Berani mencoba hal baru & 2 & 2 & 8 & 8 \\
\hline 4 & Berani maju ke depan kelas & 2 & 3 & 7 & 8 \\
\hline 5 & Tidak canggung dalam bertindak & 4 & 4 & 6 & 6 \\
\hline \multicolumn{2}{|}{} & $13 \%$ & $17 \%$ & $34 \%$ & $36 \%$ \\
\hline
\end{tabular}

Sumber: diolah dari data primer

\section{Penafsiran}

\section{Sikap Percaya Diri Siswa}

Dari hasil wawancara dengan guru kelas 1 maupun siswa, menunjukkan bahwa sikap percaya diri siswa masih rendah sebelum memanfaatkan Dreams Book. Rendahnya sikap percaya diri ditunjukkan dengan masih sulit meminta anak untuk maju ke depan kelas. Mereka merasa malu dan takut jika salah. Data awal bahwa hanya $40 \%$ siswa yang menunjukkan indikasi sikap percaya diri juga menjadi gambaran rendahnya sikap percaya diri siswa.

Pemanfaatan Dreams Book dalam pembelajaran dirasa adalah salah satu solusi untuk meningkatkan sikap percaya diri siswa. Siswa mulai berani mengungkapkan apa yang mereka inginkan dalam buku mimpi. Dari pengamatan dan wawancara dengan siswa dapat disimpulkan bahwa sikap percaya diri siswa mulai meningkat. Peningkatan ini diperkuat dengan hasil evaluasi pada kompetensi sikap percaya diri yang menunjukkan $80 \%$ siswa sudah mencapai skor diatas KKM. 


\section{Penguatan Sikap Percaya Diri melalui Dreams Book bagi Siswa Kelas I

Pemanfaatan Dreams Book sebagai Media Pembelajaran untuk Penguatan Sikap Percaya Diri.

Untuk meningkatkan sikap percaya diri siswa, guru memanfaatkan Dreams Book sebagai media pembelajaran. Melalui media ini, guru berusaha untuk menumbuhkan sikap percaya diri siswa. Siswa mulai berani dan antusias mengungkapkan semua isi hatinya dalam buku dan mulai berani mengungkapkan apa yang mereka inginkan dalam pembelajaran.Pelaksanaan pembelajaran dengan menggunakan Dreams Book untuk penguatan percaya diri, yaitu: Pertama-tama, siswa diharuskan membawa kertas karton dan digunting menjadi 4 lembar; mereka kemudian menggabungkan potongan-potongan kertas tersebut menjadi sebuah buku;setiap lembaran buku mereka tulisi sesuai arahan guru.

\section{Langkah-langkah Pembelajaran}

Guru menyiapkan power point tentang jalannya pembelajaran. Menu power point terdiri dari doa pembukaan, kompetensi inti, kompetensi dasar, tujuan dan materi pembelajaran. Dalam menu materi, langkah-langkah pembelajaran dengan pendekatan scientifik diuraikan secara lengkap dari mengamati, menanya, mengeksplore, mengasosiasi dan mengkomunikasi.

a. Mengamati

1) Mengamati gambar tentang sikap percaya diri.

2) Menyimak penjelasan tentang perilaku percaya diri

b. Menanya

Melalui motivasi dari guru mengajukan pertanyaan tentang perilaku percaya diri

c. Mengeksplore

1) Setiap siswa diminta untuk membawa koran bekas, majalah, dan gambargambar figur sepertti pemain sepak bola, pelukis, tentara, polisi, dokter, guru, petani, karyawan dan sebagainya, gunting dan lem

2) Siswa membuat buku terbuat dari karton yang terdiri dari empat halaman

3) Guru mengajak siswa untuk memikirkan cita-citanya 
4) Siswa menempel foto dirinya dan menuliskan nama panggilannya di bawah foto serta cita-citanya di bawah nama panggilannya pada buku halaman pertama

5) Guru mengajak siswa untuk mengetahui kehebatan dirinya

6) Siswa memilih gambar dari koran, majalah atau gambar figur yang menyimbolkan cita-citanya dan menempelkannya pada halaman kedua

7) Siswa menggunting gambar-gambar yang ada di koran atau majalah yang menggambarkan kehebatannya lalu tempel pada halaman ketiga

8) Siswa menggunting gambar yang ada di koran atau majalah yang menggambarkan jalan atau cara untuk mencapai cita-citanya.

9) Setelah semua pekerjaan selesai berikan kesempatan kepada siswa untuk mempresentasikan hasil pekerjaannya di depan kelas

10) Setelah seluruh peserta mempresentasikan cita-cita dan kenginannya berikan penekanan pentingnya cita-cita dan kepercayaan diri untuk mencapai cita-cita tersebut.

d. Asosiasi

1) Membuat rumusan hasil pengamatan tentang perilaku percaya diri

2) Mengidentifikasi perilaku percaya diri

e. Komunikasi

1) Siswa memberi komentar tentang penampilan temannya

2) Guru memberi penguatan

f. Evaluasi

Evaluasi dilakukan dengan observasi, penilaian diri dan penilaian antar teman sebagai penunjang data dengan memberi mengisi rubric yang telah disediakan. Pengisian rubrik adalah dengan memberi $(\sqrt{ })$ pada kolom skor sesuai sikap percaya diri yang ditampilkan siswa dengan kriteria sebagai berikut:

1 = tidak pernah, apabila tidak pernah melakukan

2 = kadang-kadang, apabila kadang-kadang melakukan dan sering tidak melakukan

3 = sering, apabila sering melakukan, dan kadang-kadang tidak melakukan

$4=$ selalu, apabila selalu melakukan sesuai pernyataan. 
Dari pelaksanaan evaluasi yang dilakukan setelah memanfaatkan media Dreams Book dalam pembelajaran didapatkan data yang dapat disimpulkan bahwa prosentase sikap percaya diri menunjukkan skor yang relatif tinggi. Siswa yang memperoleh skor 3 adalah 34\% dan siswa yang memperoleh skor 4 mencapai 36\%. Hal ini menunjukkan bahwa $80 \%$ siswa telah menunjukkan indicator percaya diri.

\section{Pembahasan}

Sikap percaya diri merupakan salah satu aspek dari Kompetensi Inti 2 yaitu kompetensi sikap sosial. Dari observasi awal disimpulkan bahwa siswa kelas 1 SDN Tegalombo 1 Tahun pelajaran 2015/2016pada awalnya kurang percaya diri dalam setiap tindakan dalam pembelajaran. Mereka masih sulit untuk diminta maju ke depan kelas atau mengutarakan pendapatnya.Oleh karena itu perlu dicari solusi agar siswa memiliki sikap percaya diri yang tinggi. Untuk meningkatkan sikap percaya diri siswa, guru memanfaatkan Dreams Book sebagai media pembelajaran. Melalui media ini, guru berusaha untuk menumbuhkan sikap percaya diri siswa. Siswa mulai berani dan antusias mengungkapkan semua isi hatinya dalam buku dan mulai berani mengungkapkan apa yang mereka inginkan dalam pembelajaran.

Pembelajaran dengan bermain Dreams Book dilakukan dengan mengajak siswa untuk membuat buku sederhana yang terdiri dari 4 halaman. Guru mengajak siswa untuk memikirkan cita-citanya. Pada lembar pertama siswa menempel foto dirinya dan menuliskan nama panggilannya di bawah foto serta cita-citanya di bawah nama panggilannya. Langkah selanjutnya, guru mengajak siswa untuk mengetahui kehebatan dirinya. Siswa memilih gambar dari koran, majalah atau gambar figur yang menyimbolkan cita-citanya dan menempelkannya pada halaman kedua. Siswa menggunting gambar-gambar yang ada di koran atau majalah yang menggambarkan kehebatannya lalu tempel pada halaman ketiga.Siswa menggunting gambar yang ada di koran atau majalah yang menggambarkan jalan atau cara untuk mencapai citacitanya dan ditempelkan pada halaman keempat.Setelah semua pekerjaan selesai berikan kesempatan kepada siswa untuk mempresentasikan hasil pekerjaannya di depan kelas. Setelah seluruh peserta mempresentasikan cita-cita dan kenginannya 
berikan penekanan pentingnya cita-cita dan kepercayaan diri untuk mencapai citacita tersebut.

Pelaksanaan pembelajaran sedikit gaduh karena siswa mulai banyak bertanya bagaimana caranya. Namun ketika siswa mulai memahami langkah langkahnya mereka tampak asyik menggunting dan menempel. Meskipun tidak semua siswa berhasil membuat seperti yang diinginkan namun mereka antusias mengikuti seluruh kegiatan dalam pembelajaran. Di akhir kegiatan guru menekankan kepada siswa bahwa mimpi yang telah mereka buat sangat bagus dan harus diupayakan untuk diraih. Salah satu cara meraih cita cita mereka adalah dengan sikap yakin akan kemampuan mereka.

Sebagai evaluasi, dilakukan dengan beberapa teknik penilaian yaitu penilaian observasi, penilaian diri dan penilaian antar teman. siswa diberi tugas untuk mengisi lembar rubrik penilaian diri yang telah disiapkan guru juga diminta untuk menilai temannya dengan cara mengisi rubrik penilaian antar teman. Untuk observasi, guru membuat rubrik observasi. Dari hasil evaluasi dapat data bahwa siswa yang memperoleh skor diatas KKM mecapai 80\% dari 20 siswa. Hal ini diambil kesimpulan bahwa sikap percaya diri siswa mulai menunjukkan peningkatan, hal ini terbukti mulai menonjolnya nilai pada tiap indikator sikap percaya diri.

\section{Kesimpulan}

Penguatan sikap percaya diri sudah dimulai dari kelas 1 Sekolah Dasar. Pada pembelajaran ini, disamping keteladanan guru, dibutuhkan metode dan media pembelajaran yang tepat agar pembelajaran menjadi lebih bermakna dan berkesan di siswa. Diharapkan dengan penggunaan media pembelajaran yang dibuat, akan memudahkan guru dalam upaya meningkatkan sikap percaya diri siswa.

Untuk membantu meningkatkan sikap percaya diri dicoba dengan memanfaatkan media pembelajaran berupa Dreams Book. Pembelajaran dengan memanfaatkan media Dreams Bookmenjadikan siswa berani mengungkapkan apa yang mereka inginkan. Hal ini membantu siswa untuk memupuk rasa percaya diri. Hasil menunjukkan bahwa indikator percaya diri siswa meningkat.Dari hasil evaluasi dapat diambil kesimpulan bahwa sikap percaya diri siswa mulai menunjukkan 


\section{Yan Vita 135 \\ Penguatan Sikap Percaya Diri melalui Dreams Book bagi Siswa Kelas I SDN Tegalombo I Kalijambe Sragen}

peningkatan, hal ini terbukti mulai menonjolnya nilai pada tiap indicator sikap percaya diri.

Agar dapat meningkatkan pemahaman terhadap sebuah kompetensi dasar yang dipelajari siswa, sebaiknya guru melakukan pengembangan media pembelajaran untuk materi-materi tentang sikap/karakter dan meningkatkan kreativitas dan inovasi-inovasi dalam memilih metode pembelajaran yang tepat sesuai karakteristik siswa dan materi. 
Penguatan Sikap Percaya Diri melalui Dreams Book bagi Siswa Kelas I SDN Tegalombo I Kalijambe Sragen

\section{Daftar Pustaka}

Badaracco, Joseph L. The discipline of building character. Harvard Business Review. March-April 1998.

Baidi.2014. Kepribadian Pendidik Perspektif Pendidikan Islam. Jurnal At-Tarbawi vol 12 no 2.IAIN Surakarta.

Bermain dalam pembelajaran diunduh 20 April 2013 http://search. smartaddressbar.com /web.php?s=metode+bermain + dalam + pengajaran

Dream Book - Buku Impian | Menjadi Pelajar Inspiratif. Diunduh hari rabu, 21 Oktober 2015.https://studenttransformers.wordpress.com/2014/05/30/motivasidream-book-buku-impian-sekolah-sma-pbb-arjasari/

Jamal Ma'mur Asmani. 2013. Buku Panduan Internalisasi Pendidikan Karakter di Sekolah. Diva Press. Jogjakarta.

Kemdikbud, 2015. Panduan Teknis Penilaian Di Sekolah Dasar. Dirjen Pendidikan Dasar. Jakarta.

Khuriyah, Subar Junanto. 2014. Peningkatan Mutu Guru Madrasah Ibtidaiyah Melalui Pelatihan Character Building. Jurnal At-tarbawi vol 12 no 2. IAIN Surakarta. Surakarta.

Kunandar. 2014. Penilaian Autentik, Penilaian Hasil Belajar Peserta Didik Berdasarkan Kurikulum 2013 suatu Pendekatan Praktis. PT RajaGrafindo Persada. Jakarta.

Yan Vita. 2014. Penilaian Otentik PAI \& Budi Pekeri, Dari Penyusunan Instrumen sampai Pengolahan Deskripsi Rapor. Rasail Media Group. Semarang. 